\title{
Pengajaran Tafsir di Dayah Terpadu Al-Muslimun, Aceh Utara: Analisis Sejarah, Metode Pengajaran dan Pengaruhnya
}

\section{The Tafsir studies at Dayah Al-Muslimun in North Aceh: Analize History, Teaching Method and Influence}

\author{
Rousydiy \\ Program Studi Akuntansi, Fakultas Ekonomi Universitas YARSI, Jalan Letjen. Suprapto, \\ Cempaka Putih, Jakarta 10510. \\ Telepon (021) 4206674, 4206675, 4206676. \\ E-mail: rousydiy@yarsi.ac.id
}

KEYWORDS History, Teaching Tafsir, Dayah, Teaching Method, Problem Solving

ABSTRACT The Islamic education is became considerable concern in Aceh from time to time and Dayah is one of the educational institution model which teaches the Quran. The weaknesses of the students both in reading and understanding the contents of Quran affected the goals and learning objectives, therefore the method of teaching is the key of learning achievement for individual who love the Quran. This study aims to identify the design and historical Tafsir studies at Dayah in Indonesia and in Aceh and analyzing the teaching method used and to know the extent influence of the methods practiced at integrated Dayah AlMuslimun in North Aceh. A qualitative study was employed to collect the data from the respondents. A semi structure interview was conducted from four subjects' teachers to explore the influence of the teaching method at Dayah Al-Muslimun Aceh. The result of study showed that the history of Tafsir studies at Dayah in Indonesia cannot be separated from the history of early spreading Islam in the Malay Archipelago. Moreover, the majority of Tafsir's teachers at integrated Dayah Al-Muslimun used translation method and telling story in their teaching method. In term of interpretation of verse the majority of teachers used "tahlili methods" (problem solving). The impact of learning Tafsir was reviewed from three aspects, namely understanding, practice, and the result of examination. Moreover, this study emphasized that the teaching methods used for teaching Tafsir are good and have a good influence on students, this proven from the good aspect of understanding, the appropriate practice and the result of examination, however it still need to be evaluated and improved. 


\section{PENDAHULUAN}

Pendidikan Islam di Aceh menjadi sorotan bagi terbentuknya generasi yang berakhlak, peran institusi pendidikan Islam seperti dayah atau pesantren sebagai salah satu sarana penghubung adalah sangat penting. Peran guru-guru pendidikan Islam semakin menantang karena bukan hanya sekedar menyampaikan ilmu tetapi juga mendidik dan membina pribadi yang baik kepada pelajar. Peran dayah sebagai sarana dalam dunia pendidikan Islam dan guru sebagai pelaksana perlu mengambil langkah yang tepat dalam menentukan metode yang digunakan dalam pengajaran sehingga memberikan pengaruh yang positif bagi pelajar dalam kehidupan (Tamuri dan Ajuhari, 2010).

Institusi dayah atau pesantren merupakan salah satu lembaga pendidikan Islam yang memiliki peranan sangat penting di masyarakat Aceh dengan harapan dapat menghasilkan alumni yang mampu menjawab tantangan zaman, namun untuk mendapatkan hasil yang sedemikian maka menjadi tanggung jawab bersama. Bagi pihak dayah penentuan pelajaran agama seperti pengajaran alQuran sebagai sumber hukum Islam sangatlah penting terutama dalam metode pengajaran yang digunakan dan pengaruhnya bagi pelajar.

Aceh merupakan provinsi yang memiliki syariat Islam yang kuat dalam kehidupan masyarakatnya. Hal ini berawal pada masa kerajaan Islam di Aceh, dan banyak ulama-ulama yang dilahirkan merupakan salah satu bentuk dari kuatnya syariat Islam di Aceh. Pendidikan Islam di Aceh sangat diperhatikan dari waktu ke waktu sehingga berdirinya banyak lembaga pendidikan yang mengajarkan ilmu agama yang digabungkan dengan ilmu akademik. Lembaga pendidikan ini dikenal dengan sebutan dayah atau pesantren. Pembinaan dan penyebaran dayah di Aceh berkembang dengan pesat di semua kawasan Aceh termasuk Aceh Utara.

Aspek pendidikan Islam mengandung salah satu unsur yaitu alQuran dan salah satu institusi yang memiliki unsur pendidikan al-Quran tersebut adalah dayah. Merujuk kepada kenyataan tersebut, maka salah satu kawasan yang memiliki perkembangan dayah yang cukup baik dari kawasankawasan di Aceh secara umum adalah kawasan Aceh Utara. Oleh sebab itu pengkaji meneliti pengajaran al-Quran di dayah terpadu di Aceh Utara yang berkaitan dengan pengajaran Tafsir dan metode pengajaran yang digunakan dan pengaruhnya. Untuk melahirkan alumni yang paham terhadap al-Quran dan isinya sebagai petunjuk hidup dan amalan adalah tujuan pendidikan Islam, maka metode pembelajaran al-Quran adalah tumpuan utamanya. Pembelajaran al-Quran adalah penting untuk melahirkan manusia yang cinta terhadap al-Quran, hal ini karena pembelajaran al-Quran bukan hanya sekedar membaca dan memahami maksud isi yang terkandung tetapi lebih kepada pengamalannya dalam kehidupan seharihari.

Pendidikan al-Quran merupakan salah satu unsur yang terkandung di dalam satuan mata pelajaran pendidikan Islam. Kelemahan para pelajar yang meliputi cara membaca ataupun memahami isi kandungan al-Quran sedikit banyak telah mempengaruhi pencapaian obyektif dan tujuan pembelajaran pendidikan Islam. Mempelajari dan mendalami kandungan al-Quran adalah penting untuk mendapatkan manusia Muslim yang membudayakan al-Quran. Hal ini karena mempelajari dan memahami al-Quran bukan sebatas membaca saja tetapi juga 
berkaitan juga dengan amalan dalam kehidupan sehari-hari.

Aceh saat ini menghadapi arus perubahan yang dapat mempengaruhi iman seseorang. Maka pembelajaran dan pemahaman al-Quran tidak seharusnya dikesampingkan, justru harus lebih ditingkatkan dan dibudayakan. Pelajar alumni lembaga pendidikan Islam seperti dayah atau pesantren harus lebih bermutu dan berkemampuan seiring dengan kemajuan teknologi dalam mendapatkan ilmu agama. Pendirian dayah secara tradisional dan terpadu merupakan satu inisiatif yang tepat yang diambil oleh pemerintah Aceh dalam membudayakan dan menjadikan masyarakat yang Islami yang salah satunya dengan membentuk badan pembinaan pendidikan dayah (BPPD). Badan tersebut didirikan sebagai pengurus yang bertujuan untuk memperhatikan perkembangan dan pembelajaran pendidikan Islam di dayah Aceh dan di sekolah menengah maupun sekolah menengah atas.

Pendidikan Islam terutama alQuran di dayah-dayah dapat dimaksimalkan dalam upaya meningkatkan kualitas pengajaran alQuran. Selain itu dayah diharapkan dapat melahirkan ulama-ulama yang memahami agama terutama al-Quran sebagai pedoman hidup demi mengembalikan kejayaan Islam di Aceh seperti zaman pertama kedatangan Islam ke Nusantara. Ulama-ulama seperti Hamzah al-Fansuri, Shams al-Din alSumatrani, Nur al Din al-Raniry, Abd alRauf al-Singkili adalah bukti ketokohan masyarakat Aceh dalam bidang ilmu agama termasuk al-Quran. Hal ini ditunjukkan dengan munculnya salah satu kitab Tafsir terawal yaitu al-Tarjum an al-Mustafi dalam bahasa Melayu karya tulis Abd al-Rauf al-Singkili seorang ulama Aceh yang merupakan alumni dari dayah (Profil Badan Pembinaan Pendidikan Dayah Aceh, 2007).

Metode pengajaran dan pembelajaran adalah kunci utama tercapainya tujuan bagi mendapatkan alumni yang ahli dalam bidang keilmuan. Adapun perkara yang terkandung dalam metode pengajaran dan pembelajaran adalah perkara yang berhubungan dengan bagaimana mata pelajaran itu disampaikan kepada pelajar. Itu semua berawal dari persiapan guru dalam mengajar, materi pengajaran yang akan disampaikan dan materi penunjang yang digunakan harus sesuai dengan bahan atau materi yang diberikan.

Berdasarkan rumusan masalah dan faktor-faktor tersebut di atas, maka pengkaji tertarik untuk membuat sebuah Penelitian yang berjudul: "Pengajaran Tafsir di Dayah Terpadu Al-Muslimun Aceh Utara: Analisis sejarah, metode Pengajaran dan Pengaruhnya". Dalam menjalankan sebuah Penelitian, obyektif Penelitian harus diberikan perhatian, dikarenakan hal tersebut berfungsi sebagai satu referensi untuk memastikan pelaksanaan penelitian dapat berjalan secara lancar dan sistematis. Obyektif penelitian yang dicapai dalam penelitian ini adalah:

1. Untuk menganalisa sejarah perkembangan pengajaran Tafsir di dayah-dayah Aceh Indonesia.

2. Untuk mengetahui metode pengajaran dan pengaruhnya terhadap pembelajaran Tafsir di dayah terpadu Al-Muslimun di Aceh utara.

\section{METODOLOGI}

Metodologi adalah salah satu cara untuk mencapai kepada tujuan penelitian dan dengannya penelitian bisa dijalankan 
secara sistematis. Dalam penelitian yang dijalankan pengkaji menggunakan metode kualitatif. Untuk pengumpulan data secara kualitatif pengkaji menggunakan kajian perpusatakaan untuk meneliti bentuk dan sejarah perkembangan pengajaran Tafsir di Aceh Indonesia. Dalam penelitian ini pengkaji berusaha untuk mendapatkan data kajian yang lengkap dan sesuai dalam bentuk buku, jurnal, dokumentasi, risalahrisalah, kertas kerja, makalah, majalah, web dan lainya dalam bentuk bahasa Melayu, Inggris dan Arab. Selain itu pengkaji menggunakan metode wawancara untuk mendapatkan data dari guru-guru dayah serta hal lain yang mendukung penelitian.

Pada tahap selanjutnya untuk metode wawancara, pengkaji melibatkan empat orang dari lima orang guru sesuai jumlah populasi guru yang mengajar mata pelajaran Tafsir didayah terpadu AlMuslimun untuk menjawab soal-soal wawancara. Soal-soal wawancara semi berstruktur terdiri dari dua bagian yaitu: bagian A berhubungan dengan data demografi dari guru pengajar dan bagian B mengandung pertanyaan-pertanyaan yang berhubungan dengan metode pengajaran Tafsir di dayah terpadu AlMuslimun. Berikut adalalah tabel sampel informasi guru pengajar Tafsir di dayah terpadu:

Tabel 1. Sampel informan guru-guru pengajar Tafsir

\begin{tabular}{lcc}
\hline Bil/kode & $\begin{array}{c}\text { Pengalaman } \\
\text { Mengajar }\end{array}$ & $\begin{array}{c}\text { Tingkat } \\
\text { pendidikan }\end{array}$ \\
\hline G01 & 4 Tahun & Sarjana Muda \\
\hline G02 & 4 Tahun & Sarjana \\
\hline G03 & 3 Tahun & Sarjana Muda \\
\hline G04 & 2,5 Tahun & Sarjana \\
\hline
\end{tabular}

Data-data yang diperoleh melalui metode ini, selanjutnya dianalisa dengan teliti dan memisahkan data yang bersifat primer dan skunder. Hal ini dimaksudkan untuk mengklasifikasikan data tersebut berdasarkan kategorinya masing-masing yang meliputi data dari kajian pustakan dan wawancara dan hasil dari data analisa diharapkan dapat memberikan hasil yang maksimal dan bermanfaat.

Metode yang digunakan pengkaji untuk menganalisa data yaitu pertama menggunakan metode kajian pustaka untuk mengetahui bentuk dan sejarah pengajaran Tafsir di dayah-dayah terpadu di Aceh Indonesia. Bab ini membicarakan sejarah dan perkembangan dayah di Aceh, ketokohan ulama-ulama Tafsir Aceh dan perkembangan pengajaran Tafsir di dayah di Aceh. Seterusnya bagian ini menguraikan dayah-dayah terpadu di Aceh utara secara umum yang berhubungan dengan pengajaran Tafsir yang sedang dijalankan.

Selanjutnya untuk analisis konten data yang diperoleh dari hasil wawancara, pengkaji menganalisis hasil wawancara dari guru-guru pengajar Tafsir untuk mendapatkan metode pengajaran yang dipakai dalam pengajaran, mengetahi pengaruhnya terhadap prestasi belajar siswa dan pengamalannya dalam kehidupan sehari hari.

\section{ISI}

Bab ini dibagi menjadi dua bagian yaitu pertama pengkaji menguraikan tentang hasil kajian pustaka tentang bentuk sejarah perkembangan pengajaran Tafsir di Dayah Aceh, ketokohan ulama-ulama Tafsir Aceh dan pengajaran Tafsir di dayah terpaduh Al-Muslimun Aceh utara. Kedua peneliti menganalisis hasil 
wawancara semi berstruktur terhadap guru-guru mata pelajaran Tafsir di dayah terpadu Al-Muslimun Aceh Utara.

\section{Sejarah Perkembangan dan Pengajaran Tafsir di Dayah-Dayah Aceh}

Pengajaran Tafsir merupakan mata pelajaran penting dalam pendidikan bidang agama terutama di dayah karena dapat mendorong banyak bidang ilmu lain seperti Fiqh, Tauhid dan Tasawwuf. Sejak awal mula munculnya dayah di masyarakat Aceh sehingga sekarang, perkembangan dayah terus berjalan mengikuti tantangan zaman. Dalam catatan sejarah, pengajaran Tafsir bermula di Aceh sehingga munculnya para ulamaulama Tafsir dari Aceh yang memberikan pengaruh kepada pengajaran Tafsir di dayah Aceh bahkan Nusantara. Hal ini menunjukkan bahwa perkembangan pengajian Tafsir di dayah Aceh mengalami perubahan dan kemajuan secara pesat, hal ini berlangsung berdasarkan perkembangan dan tantangan zaman.

Pengajaran Tafsir di Aceh pesat berkembangnya di semua kawasan Aceh. Kawasan Aceh utara adalah salah satu kawasan yang mengalami pertumbuhan dayah tersebut sama halnya terpadu maupun salafi dengan total 54 dayah (Buku Akreditasi dayah Aceh, 2012). Satuan mata pelajaran agama di dayah adalah satu perkara penting dan pengajaran Tafsir merupakan mata pelajaran utama bagi pelajar sebagai pendorong mata pelajaran yang lain.

\subsection{Pengertian Dayah di Aceh}

Perkataan dayah berasal dari perkataan zawiyah yang dalam bahasa Arab tunggal (زوية) dan jamaknya (زاويا) bermakna sudutsudut atau penjuru dalam sebuah rumah atau bangunan. Sebagai salah satu lembaga pendidikan dayah memang berasal dari pengajaran-pengajaran yang dijalankan disudut-sudut masjid yang merupakan lembaga pendidikan yang terawal dalam Islam (George, 2009). Penggunaan kata zawiyah di Masjid Haramayn sebagai tempat mendapatkan dan menyampaikan ilmu diambil dengan amalan sahabat yang mengambil sudut masjid untuk beriktikaf. Penggunaan kata sudut inilah yang menjadikan ikatan hubungan antara Haramayn dengan yang berlaku di Aceh (Syukri Mohammad, 2009). Dalam bahasa Aceh kata zawiyah ini secara berterusan dilafadzkan menjadi dayah dalam dialek Aceh, istilah ini disebut pesantren di Jawa dan seluruh Indonesia.

\subsection{Ulama-Ulama Tafsir di Aceh}

Kedatangan Islam merupakan awal dari perubahan budaya masyarakat yang telah hidup sebelumnya dengan tersiarnya agama Islam. Maka berbagai unsur budaya asli mulai menunjukkan wajah baru yang terserap dari unsur Islam (Koharuddin, 2004). Pengaruh kebudayaan Islam semakin jelas setelah Islam muncul sebagai kekuatan politik di Aceh, awalnya berdiri kerajaan-kerajaan kecil seperti kerajaan Peureulak, Pasai dan lainnya, seterusnya pada abad ke-16 disatukan menjadi kerajaan Aceh Darussalam (Sejarah 
Pendidikan Daerah Istimewa Aceh, 1984). Kerajaan-kerajaan ini mempunyai peranan dalam kewujudan pendidikan Islam di Aceh.

Kejayaan budaya Islam yang sesungguhnya berlangsung pada abad ke-17 ketika kerajaan Aceh Darussalam yang dipimpin oleh Sultan Iskandar Muda. Pada masa itu pusat-pusat pengembangan ilmu Islam tersebar di seluruh kerajaan seperti meunasah, masjid dan dayah. Tradisi pengembangan keilmuan di Aceh ditunjukkan juga dengan lahirnya tokoh-tokoh penting dalam keilmuan Islam seperti Hamzah al-Fansuri, Shams al-Din al-Sumatrani, Abd al-Rauf al-Singkili, Nur al-Din al-Raniry dan lainnya.

Bidang Tafsir di Aceh sudah menghasilkan beberapa tokoh yang berperan aktif dalam menulis kitab Tafsir dan terjemahan dari masa ke masa. Tokoh-tokoh tersebut terkenal dalam bidangnya pada abad ke-16 sehingga abad ke-18 M. Salah satu tokoh agama pada kurun abad ini adalah seorang ulama yang menulis karya Tafsir yaitu 'Abd al-Rauf bin Ali al-Fansuri atau mashur dengan sebutan Abd al-Rauf al-Singkili, beliau merupakan seorang tokoh agama, ahli tasawwuf, negarawan yang lahir pada 1615 M di Singkil dan beliau meninggal pada tahun 1695 M di Kuala Sungai Aceh (Ibrahim M, 2009).

'Abd al-Rauf telah mempelajari pelbagai ilmu seperti Fiqh, Hadits, Tafsir, Mantiq, Falsafah, Geografi, Ilmu Falaq,
Tauhid dan Perobatan. Di samping itu beliau mempelajari ilmu Tarekat Shattariyah dan Tarekat Qadariyah sehingga diberikan ijazah dari kedua Tarekat tersebut (Ibrahim M, 2009). Karya beliau sehingga kini yang dikenal dalam masyarakat adalah al-Tarjuman al-Mustafid, kitab tafsir al-Quran pertama dalam bahasa Melayu dan Miftah al-Tullab sebuah kitab fiqh besar yang menunjukkan kedalaman ilmunya (Sejarah Pendidikan Daerah Istimewa Aceh, 2003).

Tokoh Tafsir lain yang muncul pada abad ke-19 sehingga kini salah satunya adalah seorang pentafsir al-Quran yang berperanan aktif dalam mendorong pengajaran Tafsir di Aceh dan merupakan seorang dosen dekan Fakultas Shariah di IAIN Jami'ah al-Raniry Darussalam berpusat di Banda Aceh. Beliau adalah T.M. Hasbi Ash Siddiqy, dilahirkan di Lhokseumawe pada tanggal 10 Mac 1904 M / 22 Dzulhijjah 1312 $\mathrm{H}$ dari pasangan Teungku Haji Qadi Haji Husein bin Maseud dengan Teungku Amrah binti Teungku Qadhi Abdul Aziz (Balai Kajian Sejarah dan Nilai Tradisional Banda Aceh, 2003).

Data yang ditulis oleh Prof Ali Hasjmy bersumber dari pada Prof Dr Nourrzzaman Shiddiqy yaitu putra T.M. Hasbi Ash Siddiqy, ada menyatakan bahwa terdapat 95 buku yang telah dihasilkan selama beliau berkiprah di dunia pendidikan. Buku-buku yang berkaitan dengan Tafsir di antaranya adalah: Tafsir al-Nur, Tafsir al-Bayan, Sejarah 
dan pengantar ilmu Tafsir,58 ilmu-ilmu al-Quran, Tujuan alQuran dalam membina masyarakat, Mukjizat al-Quran, Tafsir Surah al-F a tihah, Tafsir surah al Kawthar dan Gubahan al-Quran (Shabri A. et al, 2003).

Tokoh Tafsir yang lainnya yaitu Putra Aceh sebagai seorang ulama lokal dan mempunyai perhatian besar dalam mendidik masyarakat untuk cinta kepada Allah SWT dan al-Quran adalah Tgk Mahjiddin Jusuf yang dilahirkan di Peusangan Aceh Utara pada tanggal 16 September 1918. Beliau merupakan anak seorang ulama sekaligus penyair bernama Tgk Fakir Jusuf. Usaha dan karya beliau adalah menterjemahkan al-Quran dalam bahasa Aceh menggunakan bahasa Syair, beliau mendapatkan dasar-dasar pendidikan dari kedua orang tuanya kemudian melanjutkan pendidikan formal di dayah Darul Sa'adah Cot Bada Peusangan dan kemudian melanjutkan pelajaran di Madrasah al-Muslim dan selesai tahun 1937, seterusnya beliau melanjutkan pendidikan di Padang tahun 1941 (Shabri A. et al, 2003). Selama empat tahun beliau berhasil menterjemahkan tiga surah al-Quran yaitu: surah Yasin, surah al-Kahfi, surah alInshirah, seterusnya beliau melanjutkan terjemahan selepas keluar dari penjara dan menyelesaikan penterjemahan alQuran secara lengkap.

Tokoh-tokoh tersebut di atas adalah sebagian dari beberapa ulama Aceh yang mempelajari ilmu Tafsir dan ilmu agama, namun ada ulama-ulama yang tidak memilik karya tulisan berbentuk buku di antaranya Teungku Haji Abdullah Ujong Rimba, beliau dilahirkan di Kampong Ujong Rimba Kabupaten Pidie pada tahun 1900. Beliau belajar ilmu agama dari pada orang tua yaitu Teungku Haji Hasyim dan sebagai alternatif pendidikan beliau dimasukkan ke dayah pertama yaitu dayah Ie Leubeu kemudian di dayah Lamsi pimpinan Teungku Panglima Polem Muhammad Daud di Kabupaten Aceh Besar (Shabri A. et al, 2003). Pada tahun 1924 beliau berangkat ke Mekkah untuk menunaikan ibadah haji dan menyambung pelajaran, beliau bermukim di Mekkah selama tiga tahun dan selama berada di sana beliau mendalami ilm Tafsir, Fiqh, Sejarah, Mantiq, Ilm Kalam dan juga berguru pada murshid tarekat al-Haddadiyah, pada 11 September 1983 beliau telah wafat.

\subsection{Perkembangan Pengajaran Tafsir di Dayah-Dayah Aceh}

Pengajaran Tafsir di Aceh mengalami pasang surut dari masa ke masa dengan melewati empat zaman, di antaranya: zaman sebelum Belanda masuk Aceh, zaman Belanda, zaman Jepang dan zaman Kemerdekaan. Zaman pertama, zaman sebelum Belanda masuk ke Aceh, seperti diketahui bahwa Islam sudah berkembang di Aceh jauh sebelum abad ke-13. Setelah terbentuk Kerajaan Islam Pertama di Peureulak pada tahun $840 \mathrm{M}$ 
maka didirikanlah tempat-tempat pendidikan Islam yang diberi nama zawiyah yang kemudian disebut dalam bahasa Aceh dayah (Sejarah Perkembangan Pendidikan di Aceh, 1978). Pendidikan di sini terdiri dari pendidikan dasar dan menengah baru pada awal abad ke-10 M didirikan pusat pendidikan agama yang lengkap sebelum kedatangan Belanda ke Aceh.

Peringkat kedua pada zaman Belanda, ketika penjajahan Belanda mulai masuk ke Aceh pada tahun 1873 hampir semua dayah mengalihkan aktivitasnya ke arah perjuangan fisik melawan Belanda. Dalam perang ini banyak ulama yang hilang karena syahid di Medan perang melawan Belanda, hal ini berlangsung sehingga tahun 1912 dan sejak tahun 1913 ulama yang tidak syahid dalam perang mulai berusaha untuk menghidupkan kembali dayah-dayah diseluruh Aceh, usaha ini tidak semudah pada zaman sebelum Belanda datang dan masuk ke Aceh. Pada tahun 1905 Belanda menetapkan peraturan pengawasan pemerintah terhadap pengajaran di Jawa dan Madura seterusnya ditetapkan juga di Aceh. Akibatnya, maka dayah-dayah yang dibangun sesudah masa tersebut tidaklah setaraf dengan dayah-dayah sebelum perang melawan Belanda. Mata pelajaran mulai dibatasi oleh Belanda di antaranya adalah pelajaran keterampilan, sejarah Islam dan Tafsir.

Peringkat ketiga, zaman Jepang, situasi mengenai pendidikan agama pada saat itu secara umumnya telah merosot. Pengajaran di rumah, meunasah dan masjid sepi atau boleh dikatakan tidak ada sama sekali. Hal ini disebabkan oleh suasana ekonomi yang sangat menekan sehingga ketua keluarga sangat sibuk untuk mencari rezeki, ditambah lagi sebagian waktu harus digunakan untuk kerja paksa dalam rangka membuat pertahanan untuk tentara Jepang. Ketiadaan minyak tanah juga menjadi faktor penting dari sepinya pengajian tersebut, begitu juga di madrasah-madrasah jauh dari pada faktor sempurna kerana kekurangan alat dan buku untuk belajar (Sejarah Perkembangan Pendidikan di Aceh, 1978).

Dayah-dayah di seluruh Aceh pada umumnya sepi bahkan ada yang kosong. Lebih-lebih lagi setelah terjadi pemberontakan di Aceh Utara yang dilakukan oleh pimpinan Dayah Tengku Abdul Jalil bersama murid-muridnya yang mengakibatkan kepada semua dayah di Aceh dicurigai oleh Jepang. Hal ini mengakibatkan kepada terhambatnya pengajaran agama di dayah termasuk pengajian Tafsir. Masa keempat, masa zaman kemerdekaan, yaitu yang berhubungan dengan pendidikan di Aceh setelah Jepang menyerah pada sekutu tanggal 14 Agustus 1945 mengalami pertumbuhan dari aspek pendidikan agama. Hal ini ditunjukkan dengan penyerahan sekolah-sekolah agama kepada pemerintah daerah Aceh dan kembali aktif pengajian di meunasah, rangkang dan Jami'ah. Selain itu Normal Islam 
Institut di Bireun yang pada zaman Jepang diperintahkan mengubah namanya menjadi Perguruan Normal Islam diserahkan juga kepada pemerintah dan dipindahkan ke Kutaraja (sekarang Banda Aceh), kemudian berubah nama menjadi Sekolah Menengah Islam. Perkembangan juga diikuti dengan berdirinya Institut Agama Islam Negeri al-Raniry (IAIN) yaitu cabang ketiga setelah Jogyakarta dan Jakarta dengan memiliki tiga fakultas di antaranya: Fakultas Syariah, Fakultas Tarbiyah dan Fakultas Usuluddin. Maka pengajaran di Aceh mulai dari pengajian alQuran di rumah-rumah, surau, meunasah, masjid hingga jami'ah sudah dapat aktif kembali walaupun tidak seperti masa-masa kejayaannya sebelum Belanda masuk ke Aceh.

\subsection{Sejarah dan Objektif Pendirian Dayah Al-Muslimun Aceh Utara}

Era globalisasi ditunjukkan dengan kemajuan ilmu pengetahuan dan teknologi terutama kemajuan teknologi informasi. Keadaan ini akan memberikan pengaruh secara langsung terhadap pola kehidupan masyarakat, sama halnya positif ataupun negatif seperti masyarakat di Aceh Utara dengan berkembangnya menjadi zon industri sejak tahun 1980-an. Hal ini terlihat dari perubahan pola hidup dan perekonomian masyarakat, dari agraris menjadi usahawan. Menyadari perubahan pola hidup tersebut serta pengaruh negatif yang ditimbulkan, oleh karena itu seorang putera Lhoksukon yaitu H.Rusli Puteh (alm) berinisiatif mendirikan sebuah lembaga pendidikan Islam yang dapat mendidik dan membina putra-putri bangsa yang memiliki keseimbangan ilmu pengetahuan dan teknologi dengan wawasan keimanan dan ketaqwaan, inisiatif tersebut mendapat dukungan masyarakat Lhoksukon.

Setelah mendapatkan lokasi yang strategis, sama halnya dari aspek tempat maupun keadaan tanahnya yaitu sebidang tanah dengan luas sekitar lebih kurang 14 hektar, maka beliau mulai melakukan pembangunan ruang belajar dengan bangunan dua tingkat dengan 16 ruang kelas, kantor, dapur dan asrama yang dilengkapi kamar mandi. Pembangunan ini selesai dilaksanakan pada tahun 1991. Pada tahun akademik 1991/1992 dimulai dengan penerimaan pelajar baru sejumlah 500 orang. Pada saat itu, pelajar hanya diwajibkan membayar uang untuk makan sedangkan untuk biaya asrama, pendidikan dan lainnya disubsidi langsung oleh H.Rusli Puteh. Namun akibat kemerosotan usaha dan ekonomi beliau, maka kemampuan mensubsidi pendidikan mulai menurun sehingga mengakibatkan kepada penurunan jumlah santri.

Pada tahun 1994 hingga tahun 1996, jumlah santri berkurang sehingga 200-250 orang, angka ini pun terus menurun pada sesi persekolahan tahun 1996-1997. Pelajar hanya 
tinggal 116 orang saja, maka untuk mengatasi masalah ini, H.Rusli Puteh mengambil sikap menyerahkan pengelolaan Dayah Terpadu Al-Muslimun dan seluruh assetnya kepada Drs. H.T. Syarifuddin yang saat itu menjawat jabatan sebagai camat Lhoksukon. Sebagai pemegang amanah, Drs. H.T. Syarifuddin membentuk sebuah badan pengurus untuk melanjutkan operasi dan pengelolaan pendidikan Dayah Terpadu AlMuslimun Lhoksukon. Pengurus tersebut terdiri dari Ketua Umum: Drs.H.T. Syarifuddin, Wakil Ketua I: H.Ray Alamsyah, Wakil Ketua II: Taufik Ismail Johan, Sekretaris: Zulkhairi Wahidi, Bendahari: H.Kamaluddin Kaoy.

Badan pengurus ini berusaha semaksimal mungkin melakukan perbaikan dalam segala aspek pada administrasi, manajemen, maupun keuangan, mencari sumber sumber keuangan untuk melanjutkan subsidi sehingga Dayah Terpadu AlMuslimun dapat berjalan kembali secara maksimum. Pada sesi persekolahan tahun 1997-1998 jumlah santri mulai mengalami peningkatan sehingga 458 orang, seterusnya dalam usaha perbaikan sektor administrasi dan pengurusan, badan pengurus memandang perlu membentuk sebuah yayasan yang dapat diberikan tanggung jawab pengurusan aset dayah secara keseluruhan, maka dengan Notaris Bukhari Muhammad SH. No.35 tanggal 18 September 1998 terbentuklah Yayasan Pendidikan
Islam Al-Ma'had Al-Ashry AlMuslimun (Johan TI, 2005).

Pada tanggal 9 Desember 1998, Drs. H.T. Syarifuddin selaku penerima amanah dari H.Rusli Puteh menyerahkan pengurusan Dayah Terpadu AlMuslimun kepada Yayasan Pendidikan Islam Al-Ma'had AlAshry Al-Muslimun Lhoksukon, penyerahan ini dilakukan dengan Sijil Notaris Bukhari Muhammad, SH. No.19 tanggal 9 Desember 1998, maka Dayah Terpadu AlMuslimun resmi dibawah pengurusan Yayasan Pendidikan Islam Al-Ma'had Al-Ashry AlMuslimun sampai kini. Dayah Terpadu Al-Muslimun merupakan lembaga pendidikan Islam berbentuk Islamic Boarding School dengan menerapkan perpaduan kurikulum antara dayah tradisional, dayah modern dan kementerian agama (Rahmatillah A, 2013). Dayah Terpadu AlMuslimun meletakkan visi yaitu menjadi dayah terpadu unggul dalam melahirkan cendekiawan Muslim yang memiliki kemantapan aqidah, keluhuran akhlaq, dan keluasan ilmu melalui pendidikan yang integratif dan komprehensif (Rahmatillah A, 2013). Misi dalam menerapkan program-program pendidikan tersebut di antaranya ialah menyelenggarakan pendidikan tingkat tsanawiyyah dan aliyah berdasarkan konsep pendidikan Islam, mengaplikasikan kurikulum pendidikan Kementerian Agama dan kurikulum dayah tradisional dan modern. Untuk mendapatkan 
alumni yang beriman dan beramal dengan Islam secara kaffah, berwawasan dan berpengetahuan luas, menguasai ilmu-ilmu agama khususnya dalam hafalan alQuran dan al-Hadith, mampu berkomunikasi dengan bahasa Arab dan Inggris. Menguasai keterampilan, teknologi dan berorganisasi, menciptakan pelajar yang memiliki pola hidup berdikari sama halnya bagi diri sendiri dan masyarakat (Hurman S, 2010).

\subsection{Pengajaran Tafsir di dayah Terpadu Al-Muslimun}

Dayah Terpadu AlMuslimun menerapkan dua sistem pendidikan formal dan informal. khusus untuk bidang formal metode klasik menjadi sangat penting bagi penyampaian ilmu pengetahuan, maka sebagai pendorong metode ini dayah merencanakan program kerja bagi setiap bidang. Salah satunya adalah koordinator kegiatan belajar mengajar (KBM) yang bertanggung jawab atas kelancaran jalannya kegiatan belajar mengajar sebagai tugas utama (Rahmatillah A, 2013). Bagi mata pelajaran yang diajarkan di dayah, jabatan pengajaran mempunyai tugas sebagai pengatur jadwal pelajaran selama satu tahun yang dibahagikan kepada dua semester yaitu pertengahan tahun pertama dan akhir tahun. Secara umumnya untuk seluruh subjek dan khususnya Tafsir telah dibagikan waktu bagi tiap-tiap tingkatan yang ada.
Pengajaran Tafsir yang telah dijadwalkan adalah untuk tingkatan pertama mata pelajaran Tafsir diberikan satu kali dalam satu minggu dengan masa $2 \times 45$ menit dan didukung dengan mata pelajaran al-Quran satu kali dalam seminggu, sedangkan tingkatan dua dan tingkatan tiga mempunyai jadwal dan mata pelajaran yang sama dengan tingkatan satu, jadwal ini berlaku untuk peringkat thanawiyyah (Budiman, 2013). Bagi peringkat Aliah, maka subjek pengajian tafsir ditambah dengan dorongan subjek ilmu tafsir, untuk kelas satu Aliah subjek Tafsir mulai dijadwalkan satu kali seminggu dan ditambahkan dengan materi ilmu tafsir satu kali seminggu dengan waktu $2 \times 45$ menit. Ada penambahan mata pelajaran yang membantu dan membuka wawasan pelajar dalam mempelajari tafsir supaya lebih mudah yaitu al-Quran dan alHadith.

Manakala untuk kelas dua dan tiga Aliah mempunyai jadwal dan waktu yang sama yaitu mata pelajaran tafsir dan ilmu Hadist (Hasanuddin, 2013). Ini adalah gambaran tentang pengajaran tafsir yang berlaku di Dayah Terpadu Al-Muslimun secara umumnya mengikut jadwal tahunan akademik di dayah terpadu.

Mempelajari berbagai bidang ilmu yang terkandung didalam al-Quran seperti tafsir merupakan suatu hal penting pada zaman modern supaya tujuan dalam hidup menjadi jelas sebagaimana yang dimaksudkan dalam al-Quran. Kini 
masyarakat banyak melakukan kegiatan pengajaran tafsir ditempat yang berbedabeda seperti di masjid, surau, dayah dan lainnya. Dayah adalah salah satu tempat diajarkan cara membaca, menghafal hingga mentafsirkan al-Quran. Hal ini penting sebab peranan dayah dalam mengenalkan keilmuan Islam dan alQuran dalam masyarakat, dimulai pada abad ke-15 hingga kini dan dayah sebagai sebuah lembaga pendidikan yang mendidik dan membentuk generasi muda yang berakhlaq mulia.

Dayah sendiri mengalami tiga peringkat perkembangannya sejak masuknya Islam ke Aceh yaitu masa perkenalan dan penyebaran Islam. Peringkat kedua yaitu waktu kejayaan dayah, ditunjukkan dengan berdirinya dayah-dayah hingga dayah manyang Baiturrahman dengan pelbagai kajian bidang keilmuan. Peringkat ketiga yaitu zaman kemunduran pada perkembagan ilmu di dayah akibat datangnya penjajah Belanda sehingga banyak dayah yang ditutup dan perpustakaan dibakar karena bergejolaknya perang pada masa itu. Namun semangat ulama begitu besar dalam mempertahankan dayah sehingga dapat ditemui pada masa kini. Dayah telah banyak menghasilkan ulama-ulama yang bergerak dalam bidang tafsir di antaranya adalah Abd al-Rauf al-Singkili yang terkenal di Aceh, Nusantara dan Arab, T.M. Hasbi Ash-Shiddiqy dan tokoh lainnya.

\section{Analisis Hasil Wawancara Pengajar Tafsir di Dayah Aceh Utara}

Wawancara ini dibagi menjadi sub topik tertentu agar lebih teratur dan mudah dipahami. Bagi menjawab objektif kedua dalam penelitian ini yaitu menganalisis metode pengajaran yang digunakan dalam pengajaran tafsir, maka pengkaji telah menggunakan metode wawancara semi terstruktur dan pembahasan dalam penelitian ini menunjukkan hasil kajian yang berfokus kepada guru pengajar tafsir saja sebagai responden, sementara pertanyaan wawancara dibahas dalam sub bagian seterusnya. Terdapat delapan tema yang dibentuk bagi menjawab pertanyaan dalam wawancara ketiga dalam penelitian ini yaitu:

1. Kaedah pengajaran dan pentafsiran ayat dalam pengajaran di dayah

2. Kurikulum dan buku panduan dalam pengajaran tafsir di dayah

3. Mengukur keberhasilan metode pengajaran yang dipakai

4. Alat bantu mengajar dalam pengajaran

5. Pengajar menghubungkan mata pelajaran dengan kehidupan nyata

6. Menyimpulkan mata pelajaran yang telah disampaikan kepada pelajar

7. Metode yang paling berpengaruh kepada pelajar

8. Bagaimana menilai pelajaran yang telah disampaikan

\subsection{Metode Pengajaran dan Pentafsiran Ayat dalam Pengajran Tafsir di Dayah}

Pada bagian ini menjelaskan hubungan antara "metode pengajaran dan pentafsiran ayat yang dijalankan oleh guru dalam pengajaran tafsir". Penjelasan dituliskan dalam bentuk naratif, seterusnya dijelaskan dalam bentuk wawancara. Secara umum semua guru mengajar sesuai metode yang ada dalam pengajaran tafsir, namum setiap individu mempunyai metode tersendiri dalam mengajar sama halnya ada satu metode atau lebih.

Menurut pengalaman guru-guru pengajar tafsir, metode yang digunakan dalam pengajaran tafsir adalah berdasarkan metode terjemah 
dan bercerita berikut petikan hasil wawancara yang telah dijalankan:

Responden G01 mengungkapakan bahwa;

".saya menggunakan metode terjemah dan kadang-kadang saya menggunakan metode bercerita ....".

Responden G02 mengatakan bahwa;

“.....pertama saya menggunakan metode terjemah kemudian saya teruskan dengan menggunakan metode bercerita....".

Responden G03 menyatakan bahwa;

"......saya menggunakan metode hafalan dan sebelum dimulai pelejaran para pelajar menghafalkan surah didepan kelas dan memahami kandungan ayat dengan terjemah, seterusnya pelajar menguraikan tentang apa yang telah dipelajari .....".

Responden G04 mengatakan bahwa;

“......saya menggunakan metode terjemah dan metode tanya jawab dengan berdialog interaktif ....".

Uraian dari pada pengalaman yang dijalankan oleh guru-guru dalam mengajar Tafsir menunjukkan bahwa setiap individu secara umum menggunakan metode bercerita dan terjemah sesuai dengan kandungan ayat mata pelajaran yang disampaikan oleh guru-guru kepada pelajar. Berkaitan dengan aspek persoalan yang dibicarakan, penelitian ini juga menjelaskan perkara yang berkaitan dengan metode setiap guru dalam pentafsiran ayat, menurut pengalaman guru-guru sebagaimana yang diungkapkan dalam petikan wawancara berikut ini;

Responden G01 mengungkapkan bahwa; “.....saya menggunakan tafsir mawdu' $i$, yaitu mentafsirkan ayat mengikut kepada setiap topik atau perkara yang akan dibicarakan....".

Responden G02 mengatakan bahwa;

"...Saya menggunakan metode ijmali dalam pentafsiran, mengikuti kandungan maksud dari pada ayat ....".

Responden G03 menyatakan bahwa;

".....saya menggunakan metode Tahlili dalam pentafsiran ayat, ini disebabkan ayat al-Quran saling berkaitan....".

Responden G04 mengatakan

bahwa;

“.... Saya menggunakan metode pentafsiran Tahlili yaitu pentafsiran analisis ayat dari berbagai aspek sama halnya dari aspek asbab al-Nuzul, aspek hukum dan lain-lain...".

Secara umum metode pentafsiran yang digunakan adalah Tahlili, hal ini peneliti dapatkan dari pada jawaban peserta wawancara yaitu peserta G03 dan peserta G04 yang menjawab menggunakan metode Tahlili, sedangkan peserta G01 menggunakan metode Mawdu'i dan peserta G02 menggunakan kaedah Ijmali.

Hal-hal ini dijalankan bagi mendapatkan bagaimana metode pengajaran dan pentafsiran dijalankan dan bagi mendapatkan pengaruh dikalangan pelajar. Analisis hasil kajian baik dari segi kitab rujukan, aspek cara untuk mengukur keberhasilan metode yang dijalankan, aspek alat bantu 
pengajaran, aspek cara menghubungkan mata pelajaran dengan kehidupan, aspek metode yang paling berpengaruh bagi pelajar dan aspek cara guru menilai pelajaran yang telah disampaikan.

\subsection{Buku Rujukan Dalam Pengajran Tafsir}

Analisis pada bagian berikut ini adalah bertemakan buku-buku rujukan atau referensi pelajaran Tafsir yang digunakan para guru pengajar dalam pengajaran Tafsir. Pengajar Tafsir diminta menjawab soal-soal wawancara yang diberikan oleh peneliti.

Responden G01 mengungkapan bahwa "....kitab yang digunakan adalah modul dayah yang disusun oleh bagian kurikulum dari dayah...",

Responden G02 “...kitab yang jadikan rujukan adalah modul yang dikutip dari kitab Safwat alTafasir karya Ali al-Sabuni dan disusun dengan ayat-ayat tertentu bagi setiap kelas...",

Responden G03 “....kitab yang digunakan adalah modul dayah dan juga mengunakan kitab Mutiara Juz 'Amma ...",

Responden G04 "....menggunakan modul dan kitab Safwat al-Tafasir karya Ali al-Sabuni sebagai rujukan dalam pengajian tafsir...". Seterusnya analisis berkaitan dengan cara guru mengukur keberhasilan metode yang dijalankan.

\subsection{Mengukur Keberhasilan \\ Metode Pengajaran yang dipakai dalam Pengajaran}

Analisis berikut ini adalah untuk mengetahui keberhasilan guru dari aspek penerapan metode pengajaran yang dijalankan sehingga pelajar dapat menerima apa yang disampaikan.

Responden G01 mengungkapkan bahwa "....kadang-kadang saya mengukur keberhasilan dengan memberikan soal-soal kepada pelajar dan saya mendengar jawaban dari soal-soal tersebut...", Responden G02 “.....saya memberikan tugas kepada pelajar untuk menterjemahkan, mentafsirkan dan menguraikan apa yang telah dipelajari...",

Responden G03 “.....saya memanggil satu atau dua orang pelajar untuk seterusnya mengulangi dan menterjemahkan apa yang telah saya sampaikan....",

Responden G04 “.....saya mendengarkan terjemah teks dan penjelasan dari pada pelajar berdasarkan kepada apa yang telah dipelajari, walaupun tidak dengan bahasa yang tepat namun dapat menjelaskan sesuai dengan topik yangdipelajari dan yang telah dibahas....".

\subsection{Alat Bantu yang digunakan dalam Pengajaran Tafsir di Dayah}

Analisis berikut berfokus kepada aspek alat bantu guru dalam mengajaran tafsir sesuai dengan metode yang digunakan setiap guru. Ungkapan dari setiap responden dari pertanyaan yang pengkaji berikan adalah seperti berikut;

Responden G01 “....kadangkadang saya menggunakan al- 
Quran dan juga menggunakan projektor untuk membantu saya menjelaskan mata pelajaran....", Responden G02 “... alat bantu yang pertama adalah saya menggunakan kitab dan yang kedua adalah projektor....", Responden G03 “......saya lebih mengajak pelajar kepada tadabbur alam dengan mengajak pelajar keluar kelas dan mempelajari alam sekitar jadi alam adalah alat bantu saya dalam mengajar....".

Responden G04 “....saya sendiri tidak menggunakan media atau bahan bantu mengajar apapun, namun saya lebih suka menggunakan metode klasik dengan pengalaman dalam kehidupan saya atau mengajak pelajar untuk banyak membuka kamus...".

\subsection{Pengajar Menghubungkan Mata Pelajaran dengan Kehidupan Nyata}

Pada bagian ini juga pengkaji membicarakan tentang aspek bagaimana guru menghubungkan mata pelajaran dengan kehidupan nyata, berikut merupakan tanggapan responden terhadap pertanyaan dari peneliti;

Responden G01 mengungkapkan bahwa ".....saya mengkaitkan sesuatu dengan kehidupan seharihari yang sesuai dengan topik yang dibahas .....",

Responden G02 “....ketika saya membicarakan akhirat, maka saya akan menghubungkan kehidupan dunia dengan akhirat dan muamalah dengan manusia dan dengan sang pencipta...",
Responden G03 “.....mengajak pelajar untuk berfikir dan melihat alam sekitar bahwa ciptaan Allah SWT bukan hanya manusia ....", Responden G04 menyatakan “....saya meminta pelajar untuk mengaitkan mata pelajaran yang dipelajari dengan kehidupan seperti masalah akhlak....".

\subsection{Menyimpulkan Mata Pelajaran} yang telah disampaikan kepada Pelajar

Analisis ini berfokus kepada bagaimana guru menyimpulkan mata pelajaran yang telah disampaikan kepada pelajar. Dalam hal ini setiap guru mempunyai cara berbeda dalam menyimpulkan mata pelajaran yang telah diberikan, berikut jawaban peserta atas pertanyaan yang diberikan pengkaji;

Responden G01 mengungkapkan bahwa "....dengan memberikan catatan, kadang-kadang menulis di papan putih dan juga membaca kepada pelajar.....",

Responden G02 “.....saya menyimpulkan sesuai dengan apa yang telah ada didalam modul dan juga dengan cara menjawab soalan....",

Responden G03 “.....saya memberikan catatan kepada pelajar atau dengan membacakan kepada pelajar.....",

Responden G04 “....saya meminta kepada pelajar supaya masing-masing memberikan kesimpulan terhadap mata pelajaran yang telah disampaikan dan dipelajari.....". 


\subsection{Metode yang Paling \\ Berpengaruh Untuk Pelajar Terhadap Pembelajaran Tafsir}

Analisis tema berikutnya berkenaan dengan pandangan guru berkaitan dengan metode yang paling berkesan kepada pelajar selama pengajaran tafsir yang dijalankan. Secara keseluruhannya peserta memilih metode bercerita karena dianggap yang paling berkesan, berikut ungkapan dari pada Responden G01 dalam hal ini ialah:

“......dari dua metode yang saya ungkapkan tadi yaitu metode terjemah dan metode bercerita, saya melihat pelajar lebih berkesan kepada metode bercerita, selain dapat melihat terjemah ayat tersebut mereka (pelajar) dapat menikmati dan mendengar cerita yang disampaikan...." (Responden G01).

Begitu juga tanggapan dari pada Responden G02 adalah berikut ungkapannya:

“.....saya melihat bahwa pelajar lebih suka kepada metode bercerita dalam menguraikan mata pelajaran yang disampaikan...." (Responden G02)

Selain itu, ungkapan pendapat dari apa yang disampaikan Responden G03 tentang metode yang berpengaruh bagi pelajar adalah seperti berikut:

"...metode bercerita adalah metode yang berpengaruh bagi pelajar sebab dengan ini pelajar lebih mudah memahami dan merekam apa yang disampaikan guru...."

(Responden G03)

Responden terakhir G04 juga mengungkapkan pendapatnya tentang metode yang berpengaruh bagi pelajar berdasarkan kepada pengalaman dalam mengajar tafsir yaitu seperti

berikut:

“....pelajar lebih suka kepada metode tanya jawab dan juga metode bercerita, namun pelajar lebih suka pembahasan yang diuraikan guru dikaitkan dengan metode yang ada dalam kehidupan nyata dan diambil contoh bagi kehidupan pelajar......"

(Responden G04)

\subsection{Bagaimana Menilai Pelajaran Yang Telah Disampaikan}

Analisis berikutnya adalah pertanyaan pengkaji kepada responden yang berhubungan dengan hal menilai mata pelajaran yang dilakukan oleh guru terhadap mata pelajaran yang disampaikan;

Responden

G01

mengungkapkan, “....saya mengukur nilai pelajar dengan cara memberikan pengulangan pembelajaran kepada pelajar, untuk mengetahui sejauh mana para pelajar dapat menguasai apa yang telah saya berikan....",

Responden G02 “...saya menilai dengan memberikan semacam ulangan kepada para pelajar dan juga soal-soal ujian...",

Responden G03 “...sebelum memulai pelajaran saya menguji beberapa pelajar 
untuk menjelaskan pelajaran yang telah dipelajari pada pertemuan sebelumnya...jika dapat menjelaskan, maka menurut saya dia sudah berhasil memahami maksud dari apa yang telah kami pelajari...".

Responden G04 mengatakan bahwa “...saya menilai dengan cara lisan atau tulisan, contoh cara lisan ialah soal tanya jawab tentang pelajaran sebelum dimulai pelajaran baru.

\section{Kesimpulan Hasil Wawancara Pengajar Tafsir di Dayah Terpadu}

Analisis ini menjelaskan tentang hasil Penelitian yang telah dijalankan menunjukkan bahwa mayoritas guru pengajar Tafsir di dayah terpadu AlMuslimun menggunakan metode terjemah dan bercerita dalam mengajar tafsir, sedangkan dalam hal pentafsiran ayat mayoritas guru menggunakan metode tahlili yaitu mentafsirkan ayat-ayat al-Quran dengan memaparkan berbagai aspek yang terkandung di dalam ayat-ayat yang sedang ditafsirkan. Selain itu guru menerangkan makna-makna yang termasuk di dalamnya sesuai dengan keahlian dan kecenderungan dari mufasir yang mentafsirkan ayat-ayat tersebut (Nasruddin, 2002).

Adapun kaitan dalam hal ini, pengkaji dapatkan dari wawancara yang dijalankan yaitu Responden G01 sehingga Responden G04 masingmasing menggunakan metode ini dalam mengajar, sedangkan metode bercerita sebagai pendorong dan menghubungkan mata pelajaran yang dijalankan. Dari hasil wawancara pengkaji dapatkan bahwa seluruh responden G01 sehingga G04 mengungkapkan bahwa metode bercerita memberikan kesan yang banyak bagi pelajar sehingga para pelajar mudah memahami maksud dan tujuan ayat al-Quran yang diberikan dibantu dengan kaedah terjemah.

\section{PENUTUP}

Penelitian ini dijalankan bertujuan untuk meneliti bentuk dan sejarah pengajian tafsir di dayah di Indonesia. Penelitian ini juga mencoba mengkaji sejarah perkembangan pengajaran tafsir di Aceh dan seterusnya kajian ini juga dibuat untuk menganalisa metode pengajaran yang digunakan dan pengaruhnya dalam pengajaran tafsir di dayah Terpadu Al-Muslimun di Aceh Utara.

Sejarah masuknya Islam ke Nusantara adalah hal terpenting dalam proses perkembangan tafsir di Nusantara dan Indonesia. Sejarah tafsir juga ditunjukkan melalui gerakan pembaharuan Islam di Nusantara yaitu ulama abad ke-17 adalah Hamzah alFansuri dan Shams al-Din al-Sumatrani. Keduanya merupakan intelek Muslim berpengaruh dalam pembaharuan Islam di abad ke-17. Setelah itu muncullah seorang ulama terkenal yaitu 'Abd alRauf al-Singkili (1615 M-1695 M), beliau dikenal sebagai seorang ulama dan mufasir terawal yang menulis sebuah kitab tafsir lengkap 30 juz dengan berjudul al-Tarjum an al-Mustafid.

Dayah memiliki peranan penting dalam pendidikan Islam di Aceh dalam berbagai bidang ilmu sejak abad ke-17, hal ini ditunjukkan dengan perkembangan sistem pendidikan di dayah dalam mencapai tujuan memajukan agama dan masyarakat Aceh, mulai dari perubahan bentuk salafi kepada terpadu seperti kini banyak di 
Aceh. Dayah pertama di Aceh bernama Dayah Cot Kala yang dipimpin oleh Tgk Muhammad Amin atau yang lebih dikenal dengan Tgk Chik Cot Kala, kemudian beliau menjadi Raja Peureulak, para alumni dari dayah ini menyebarkan Islam ke seluruh Aceh dan mendirikan dayah-dayah.

Bagi mendapatkan metode pengajaran yang diinginkan dalam pengajaran tafsir, maka pengkaji menggunakan metode wawancara semi berstruktur kepada empat orang guru mewakili $80 \%$ dari jumlah lima orang guru yang mengajar mata pelajaran tafsir. Dari hasil analisis menunjukkan bahwa mayoritas guru pengajar Tafsir di dayah terpadu Al-Muslimun menggunakan metode terjemah dan bercerita dalam mengajar tafsir didayah terpadu. Bagi pentafsiran ayat mayoritas guru pengajar menggunakan metode tahlili yaitu mentafsirkan ayat-ayat al-Quran dengan memaparkan berbagai aspek yang terkandung di dalam ayat-ayat yang sedang ditafsirkan itu serta menerangkan makna-makna yang ada didalamnya sesuai dengan keahlian dan kecenderungan dari mufasir yang mentafsirkan ayat-ayat tersebut.

Pemilihan metode yang sesuai sangat penting di dalam proses pengajaran dan pembelajaran, sebab hal itu dapat menjamin pencapaian objektif dalam pengajaran dan dapat memastikan pengaruh yang diterima pelajar di tahap yang maksimum. Guru harus bijak dalam membuat dan menyesuaikan suatu metode terhadap mata pelajaran yang diajarkan di dalam kelas.

\section{DAFTAR PUSTAKA}

Ab Halim Tamuri Muhammad Khairul Azman Ajuhary. Amalan
Pengajaran Guru Pendidikan Islam Berkesan Berteraskan Konsep Muallim, Journal of Islamic and Arabic Education, 2010

Abdul Fatah. Sejarah Masuk dan Berkembangnya Islam di Aceh (Bahan Seminar Sejarah Masuk dan Berkembangnya Islam di Aceh, Sekretariat Majelis Ulama Daerah Istimewa Aceh 1978)

Abdul Hadi, Profil Badan Pembinaan Pendidikan Dayah Aceh, 2011.

Al-Singkili Rujuk; Ahwan Mukarrom, Konsep Syaikh Abdul Rauf Singkel Tentang Arabic Education 2(1), 2010.

Arif Rahmatillah, "Pimpinan Dayah Terpadu Al-Muslimun", Interview, 2013

Ashriy Al-Muslimun, Lhoksukon Civilisation, 2009

Daud Zamzami et al, Pemikiran Ulama Dayah Aceh, cet-1, Jakarta: Prenada, Badan Dokumentasi Kebudayaan Daerah, Jakarta, 1984 Edinburgh, University Press, 1981.

George Makdisi, the Rise of Colleges: Institution of Learning in Islam and The West, Hasanuddin, AJK Pengajaran Dan Kurikulum Aliyah, 2013

Islamiyyat 2004, vol. 26, bil.2, 28. Mengenai riwayat hidup ringkas „Abd al-Rauf Kematian Dalam Nash Lubb Al-Kashf Wa Al-Bayan, Jurnal Islamica 2009. UTM, 2001

Mazlan Ibrahim et. al, "Israiliyat Dalam Kitab Tafsir Anwar Baidawi", Jurnal Islamiyyat 2004, vol. 26, bil.2, 28. Mengenai riwayat hidup ringkas „Abd al-Rauf al-Singkili Rujuk; Ahwan Mukarrom, Konsep Syaikh Abdul Rauf Singkel Tentang Kematian Dalam Nash Lubb Al-Kashf Wa Al-Bayan, Jurnal Islamica 2009. 
Mohd Koharuddin bin Mohd Balwi, Tradisi Keilmuan dan Pendidikan Dalam Tamadun Melayu di Nusantara, Jurnal Kemanusiaan, Jabatan Pembangunan Sumber Manusia UTM.

Mohd Mohd.Syukri Yeoh Abdullah, Zaw i yah Shaykuala: Pusat Penyebaran Islam di Alam Melayu Abad ke-17 Masehi, Internasional Journal of the Malay World and Civilisation 2009.

Nasruddin Baidan, Metode penafsiran alQur'an, Kajian kritis terhadap ayatayat yang beredaksi mirip, (Yogyakarta, pustaka pelajar, 2002), Nilai Tradisional Banda Aceh 2003

Pendidikan Islam Berkesan Berteraskan Konsep Muallim, Journal of
Islamic and Rehabilitasi dan Rekonstruksi NAD-Nias, 2007

SejarahPertumbuhan dan Pembaharuan Pendidikan Islam di Indonesia, (Jakarta, Kencana Prenada Media Group), 2007

Shabri A et al, Biografi Ulama-Ulama Aceh Abad XX, cet-1, Balai Kajian Sejarah dan Nilai Tradisional Banda Aceh 2003.

Syaiful Hurman, Pekan Perkenalan Dayah Terpadu Al-Muslimun, 2010.

Taufik Ismail Johan, Buku Panduan Manual Yayasan Pendidikan Islam al-M'ahad alAshriy Al-Muslimun, Lhoksukon 2005.

Zakaria Ahmad, Sekitar Kerajaan Atjeh Dalam Tahun 1520-1675, Medan: Monora, 1972. 